\title{
Effects of Eucalyptus grandis Leaf Litter Decomposition on the Growth and Resistance Physiology Traits of Eremochloa ophiuroides
}

\author{
Yiqiao $\mathrm{Li}^{1}$, Tingxing $\mathrm{Hu}^{1}$, Fanming Zeng ${ }^{1}$, Hong $\mathrm{Chen}^{1} \&$ Xiuhua $\mathrm{Wu}^{1}$ \\ ${ }^{1}$ Key Laboratory of Forestry Ecological Engineering of Sichuan Province, College of Forestry, Sichuan \\ Agricultural University, Sichuan, China \\ Correspondence: Tingxing Hu, Key Laboratory of Forestry Ecological Engineering of Sichuan Province College \\ of Forestry, Sichuan Agricultural University, Sichuan, China. Tel: 86-835-288-2335. E-mail: \\ hutx001@yahoo.com.cn
}

Received: January 5, 2013 Accepted: January 30, 2013 Online Published: January 31, 2013

doi:10.5539/jps.v2n1p158 URL: http://dx.doi.org/10.5539/jps.v2n1p158

\begin{abstract}
In order to investigate the effect of decomposing leaf litter of Eucalyptus grandis (E. grandis) on the growth trait and resistance physiology of Eremochloa ophiuroides (E. ophiuroides), three treatments with different amounts of leaf litter were designed in this study, including A1 (30 g/pot), A2 (60 g/pot), A3 (90 g/pot), and a group without treatment $(0 \mathrm{~g} / \mathrm{pot}, \mathrm{CK})$, The blank experiment group with distilled fallen leaves were set as mentioned above. The results showed that growth traits (root length, plant height, fresh weight and dry weight) were significantly inhibited along with the increasing amounts of $E$. grandis leaf litter. The activity of CAT and SOD increased at low content of leaf litter and less processing time, but significantly dropped over time. The activity of POD was inhibited at all tested time, and all treatments were significantly lower than that in CK. The MDA content of CK was similar to that in A1 and A2, but significantly lower than that in A3 at the $30^{\text {th }}$ day after sowing, and three treatments were significantly higher than that in CK after sowing for 60 days and 90 days. The soluble sugar content went up with the increase of leaf litter content at all time points, while the change of soluble protein contents was opposite. This study demonstrated that the decomposing leaf litter of E. grandis had obviously allelopathic effect on the growth and resistance physiology characteristics of E. ophiuroides, which should be controlled rationally in the E. grandis plantation.
\end{abstract}

Keywords: allelopathy, Eucalyptus grandis, leaf litter, Eremochloa ophiuroides, osmotic adjustment material, antioxidant enzyme activity, MDA, biomass

\section{Introduction}

Eucalyptus, which are the rapid growth tree species, have produced huge economical benefit since they have been introduced into China, the ecological problems also have been emerged in recent years (Liu \& $\mathrm{Li}, 2010$ ). Previous researches showed that the Eucalyptus can break the soil water balance and reduce the soil fertility, which lead to decrease the biomass of undergrowth vegetation and simplify the community structure, ultimately resulting in biodiversity reduction and causing soil erosion (Florence, 1986; Guo, 2007). Further studies showed that allelopathic effect caused by secondary metabolism substance, so called allelochemicals, which were released from decomposing leaf litter of Eucalyptus in different ways was the main reason for these ecological problems (Niakan \& Saberi, 2009; Zhang \& Fu, 2009).

As one of the fastest growing species in Eucalyptus, the planting scope of Eucalyptus grandis has been widely expanded in south part of China due to its better traits of fast growth, strong adaptability, high economic value and wide utilization. Meanwhile, the ecological problems have been getting more and more serious with the expanding of the planting of E. grandis plantation (Wang et al., 2011).

As a main primary producer in the ecosystem, grass plays an important role in restoring the degraded ecosystem (Christian \& Wilson, 1999). The compound planting of forest and grass can not only keep the soil moisture, raise the soil fertility, improve the soil physical structure and promote the growth of trees, but also increase the yield and quality of grass due to full utilization of the beneficial microclimate in the forest, and then expand the vegetation coverage and achieve the purpose of enhancing the biodiversity and protecting the ecological environment (Wang et al., 2003; Yang, 1997). 
Eremochloa ophiuroides is a species of the genus Eremochloa (centipede grass) which contains 12 species and belongs to the family of the Poaceae. E. ophiuroides is a perennial herb, and is an important grass in keeping slope stability, lawn building and ecological protection (Islam \& Hirata, 2005). Due to its characteristics of fast growth and strong adaptability, the intercropping of E. ophiuroides and E. grandis may mitigate the ecological problems which caused by the latter. On one hand, the decomposing leaf litter of E. grandis can provide nutrition to the undergrowth, but on the other hand they also negatively affect the growth of grass in the intercropping system of forest and grass. Consequently, it is very important to test the allelopathic effect of $E$. grandis on E.ophiuroides in practice. Thus, the objective of current trial was to test the effect of decomposing E.grandis leaf litter on the growth and resistance physiology of E. ophiuroides in a natural state by the pot experiment. Results of this study could provide meaningful reference for the research on allelopathy and put forward reasonable suggestion on management of agroforestry system.

\section{Materials and Methods}

\subsection{Site for Experiment}

The experiment field was located at the Forestry Station of Sichuan Agricultural University $\left(29^{\circ} 58^{\prime} 48^{\prime \prime} \mathrm{N}\right.$, $102^{\circ} 59^{\prime} 55^{\prime \prime} \mathrm{E}, 600 \mathrm{~m}$ altitude, a. s. 1.), Ya'an, Sichuan, China. Average annual rainfall is $1800 \mathrm{~mm}$, average annual temperature is $16.2^{\circ} \mathrm{C}$ and relative air humidity is $79 \%$. The annual accumulated temperature $\left(\geq 10^{\circ} \mathrm{C}\right)$ is $5231^{\circ} \mathrm{C}$, annual sunshine is $1039.6 \mathrm{~h}$ and frost-free period is $298 \mathrm{~d}$, respectively.

\subsection{Experimental Design}

Soil used in this study is typical sandy loam soil in local place with a $\mathrm{pH}$ of 7.85 , the organic matter content is $24.38 \mathrm{~g} / \mathrm{kg}$, and the fertility condition as follows: total N $0.66 \mathrm{~g} / \mathrm{kg}$; total K $5.57 \mathrm{~g} / \mathrm{kg}$, total P $0.67 \mathrm{~g} / \mathrm{kg}$; available $\mathrm{K} 15.15 \mathrm{mg} / \mathrm{kg}$ and available P $14.73 \mathrm{mg} / \mathrm{kg}$. The soil status of control group is the same with treatments. The experimental soil was sterilized by carbendazim after sieving with $2 \mathrm{~mm}$ mesh.

Fresh fallen leaves were randomly collected from a 10-year-old E. grandis plantation in the experiment area, and then cut them into small pieces with the size about $1 \mathrm{~cm}^{2}$ after cleaning. Full and uniform E. ophiuroides seeds were selected for our research. Seeds were soaked in the warm water for $24 \mathrm{~h}$ after disinfection with $0.1 \% \mathrm{HgCl}_{2}$ for $20 \mathrm{~min}$, and then germinated for $48 \mathrm{~h}$.

Three treatments were set according to the annual amount of leaf fall in pure $E$. grandis plantation $\left(9000 \mathrm{~kg} / \mathrm{hm}^{2}\right)$, including A1 (30 g/pot), A2 (60 g/pot), A3 (90 g/pot), and a control group ( $0 \mathrm{~g} /$ pot). Each group was repeated for 10 times. Seeds were planted in the pot $(29 \mathrm{~cm}$ in diameter of opening, $17 \mathrm{~cm}$ in diameter of bottom and $22 \mathrm{~cm}$ in height) with capacity of $8 \mathrm{~kg}$ mixture of soil and weighted leaf litter. The soil moisture content was kept at $18 \%$. In order to investigate the effect of leaf litter itself on the soil permeability and aeration, the blank experiment without allelochemicals was carried out in this study. Briefly, the fallen leaves in which allelochemicals have been removed by distillation were mixed with soils, and then four groups $(0,30,6090$ $\mathrm{g} /$ pot) were applied as mentioned above.

\subsection{Indexes Measuring}

Ten plants of E.ophiuroides were randomly collected to measure the plant height, biomass and resistance physiology indexes from every group at $30 \mathrm{~d}, 60 \mathrm{~d}$ and $90 \mathrm{~d}$ after sowing.

The roots and shoots from plants were dried in the oven at $105{ }^{\circ} \mathrm{C}$ for $30 \mathrm{~min}$ to deactivate enzymes, then dried at $80^{\circ} \mathrm{C}$ to constant mass for measurement of dry mass (overground part and underground part).

Fresh leaves were ground and extracted with frozen $0.1 \mathrm{M}$ Tris- $\mathrm{HCl}$ buffer ( $\mathrm{pH} 7.8)$ using mortar and pestle. The homogenate was centrifuged $\left(5,000 \mathrm{rpm}\right.$ for $\left.15 \mathrm{~min} ; 4^{\circ} \mathrm{C}\right)$ and then used the supernatant to test enzymes activity. The assay of superoxide dismutase (SOD) activity was carried out based on the measurement of nitroblue tetrazolium (NBT). One unit of SOD activity was determined as the amount of enzyme required to cause 50\% inhibition of the reduction of NBT as monitored (Giannopolitis \& Ries, 1977). Peroxidase (POD) activity was detected with the modified procedure (Curtis, 1971). The reaction mixture contained $7.2 \mathrm{mM}$ guaiacol, $50 \mathrm{mM}$ phosphate buffer ( $\mathrm{pH} 5.8), 11.8 \mathrm{mM} \mathrm{H}_{2} \mathrm{O}_{2}$ and $0.5 \mathrm{ml}$ enzyme was extracted in a final volume of $4.0 \mathrm{ml}$. The reaction was started by the $\mathrm{H}_{2} \mathrm{O}_{2}$ and the $470 \mathrm{~nm}$ absorbance was tested. Activity was calculated using the extinction coefficient $\left(26.6 \mathrm{mM}^{-1} . \mathrm{cm}^{-1}\right.$ at $\left.470 \mathrm{~nm}\right)$ for tetraguaiacol per min. The activity of catalase (CAT) activity was measured by determining the decomposition rate of $\mathrm{H}_{2} \mathrm{O}_{2}$ at $240 \mathrm{~nm}$ (Aebi, 1984). The $3.0 \mathrm{ml}$ reaction mixture contained 50mM K-phosphate buffer ( $\mathrm{pH} 7.0$ ), $0.2 \mathrm{ml}$ enzyme extract and $33 \mathrm{mM} \mathrm{H}_{2} \mathrm{O}_{2}$ in a final assay. The malondialdehyde (MDA) was measured by the thiobarbituric acid (TBA) test (Heath \& Packer, 1968). The soluble protein content was tested with staining of coomassie brilliant blue $R 250$, and followed the procedure by Zhang (Zhang, 2006). The soluble sugar content was measured by sulfuric anthrone reaction as 
described by $\mathrm{Li}(\mathrm{Li}, 2000)$.

\subsection{Statistical Analysis}

One-way analysis of variance (ANOVA) was employed to compare the effect of treatments and LSD method was used for multiple comparison tests. Statistical analysis was performed by SPSS 18.0 software $(P<0.05)$.

Response index $(R I)$ of allelopathy was calculated using the formula below, as described by Williamson and Richardson (1988):

$R I=1-\mathrm{C} / \mathrm{T}(\mathrm{T} \geq \mathrm{C})$ and $R I=\mathrm{T} / \mathrm{C}-1(\mathrm{~T}<\mathrm{C})$

In the model, $\mathrm{C}$ represents the control response and $\mathrm{T}$ represents the treatment response. The range of $R I$ is from -1 to +1 . The positive value indicates stimulation by treatment, whereas the negative value indicates inhibition by treatment, comparing with the control.

\section{Results}

\subsection{Effect of Decomposing Leaf Litter of E grandis on the Growth Indexes of E ophiuroides}

The growth indexes (root length, plant weight, fresh weight and dry weight) in treatments were significantly affected by decomposing leaf litter of $E$. grandis at all tested time points, compared with those in the control group $(P<0.05)$, and these four indexes dropped with the rising of leaf litter content (CK $>\mathrm{A} 1>\mathrm{A} 2>\mathrm{A} 3)$ (Table 1). When comparing within different treatments, root length, plant height, fresh weight and dry weight in A3 were significantly higher than those in A1 and A2 at the day of $30(P<0.05)$, but no significant difference was found between A1 and A2 group except for the fresh weight. At the day of 60 , significant differences were observed in all growth indexes among A1, A2 and A3 treatments, and specifically, A1>A2>A3 $(P<0.05)$. At the day of 90 , root length in $\mathrm{A} 2$ and $\mathrm{A} 3$ group were significantly higher than that in $\mathrm{A} 1$, and $\mathrm{A} 3$ was obvious greater than $\mathrm{A} 1$ in dry weight $(P<0.05)$, however, the plant heights were similar in $\mathrm{A} 1, \mathrm{~A} 2$ and A3 $(P>0.05)$.

Table1. Effect of decomposing leaf litter of E. grandis on the growth indices of E. ophiuroides

\begin{tabular}{|c|c|c|c|c|c|c|c|c|c|}
\hline $\begin{array}{l}\text { Days after } \\
\text { sowing (d) }\end{array}$ & Groups & $\begin{array}{l}\text { Root length } \\
\quad(\mathrm{cm})\end{array}$ & $R I$ & $\begin{array}{l}\text { Plant height } \\
\text { (cm) }\end{array}$ & $R I$ & $\begin{array}{c}\text { Fresh weight } \\
\text { (g/plant) }\end{array}$ & $R I$ & $\begin{array}{l}\text { Dry weight } \\
\text { (g/plant) }\end{array}$ & $R I$ \\
\hline \multirow{4}{*}{30} & CK & $7.71 \pm 1.29^{\mathrm{a}}$ & & $9.66 \pm 2.89^{\mathrm{a}}$ & & $0.48 \pm 0.17^{\mathrm{a}}$ & & $0.15 \pm 0.02^{\mathrm{a}}$ & \\
\hline & A1 & $6.55 \pm 1.61^{\mathrm{b}}$ & -0.284 & $8.81 \pm 1.71^{\mathrm{ab}}$ & -0.187 & $0.41 \pm 0.03^{\mathrm{a}}$ & -0.091 & $0.11 \pm 0.05^{\mathrm{b}}$ & -0.119 \\
\hline & A2 & $6.16 \pm 1.12^{\mathrm{b}}$ & -0.344 & $7.41 \pm 0.91^{\mathrm{b}}$ & -0.298 & $0.26 \pm 0.01^{\mathrm{b}}$ & -0.261 & $0.09 \pm 0.01^{\mathrm{b}}$ & -0.289 \\
\hline & A3 & $4.69 \pm 1.31^{\mathrm{c}}$ & -0.455 & $6.81 \pm 0.94^{c}$ & -0.401 & $0.18 \pm 0.01^{\mathrm{c}}$ & -0.413 & $0.04 \pm 0.01^{\mathrm{c}}$ & -0.434 \\
\hline \multirow{4}{*}{60} & $\mathrm{CK}$ & $11.95 \pm 3.43^{\mathrm{a}}$ & & $18.89 \pm 2.35^{\mathrm{a}}$ & & $1.26 \pm 0.19^{\mathrm{a}}$ & & $0.29 \pm 0.05^{\mathrm{a}}$ & \\
\hline & A1 & $8.93 \pm 3.39^{b}$ & -0.311 & $16.13 \pm 2.19^{b}$ & -0.301 & $0.74 \pm 0.06^{\mathrm{b}}$ & -0.297 & $0.22 \pm 0.01^{b}$ & -0.309 \\
\hline & $\mathrm{A} 2$ & $7.83 \pm 2.29^{\mathrm{c}}$ & -0.423 & $13.61 \pm 2.69^{\mathrm{c}}$ & -0.401 & $0.65 \pm 0.12^{\mathrm{c}}$ & -0.391 & $0.17 \pm 0.04^{\mathrm{c}}$ & -0.393 \\
\hline & $\mathrm{A} 3$ & $6.41 \pm 2.65^{\mathrm{d}}$ & -0.556 & $10.43 \pm 1.35^{\mathrm{d}}$ & -0.513 & $0.42 \pm 0.08^{\mathrm{d}}$ & -0.456 & $0.13 \pm 0.02^{\mathrm{d}}$ & -0.515 \\
\hline \multirow{4}{*}{90} & $\mathrm{CK}$ & $14.34 \pm 2.44^{\mathrm{a}}$ & & $29.22 \pm 4.69^{\mathrm{a}}$ & & $3.76 \pm 0.78^{\mathrm{a}}$ & & $0.78 \pm 0.15^{\mathrm{a}}$ & \\
\hline & A1 & $12.98 \pm 4.02^{\mathrm{b}}$ & -0.231 & $26.09 \pm 4.62^{\mathrm{b}}$ & -0.323 & $3.09 \pm 0.58^{\mathrm{b}}$ & -0.199 & $0.61 \pm 0.15^{\mathrm{b}}$ & -0.208 \\
\hline & A2 & $10.55 \pm 3.18^{c}$ & -0.387 & $25.83 \pm 4.65^{b}$ & -0.345 & $2.68 \pm 0.51^{\mathrm{bc}}$ & -0.359 & $0.53 \pm 0.13^{\mathrm{bc}}$ & -0.346 \\
\hline & A3 & $10.18 \pm 1.46^{\mathrm{c}}$ & -0.418 & $25.66 \pm 4.67^{b}$ & -0.349 & $2.31 \pm 0.78^{\mathrm{c}}$ & -0.406 & $0.46 \pm 0.15^{\mathrm{c}}$ & -0.421 \\
\hline
\end{tabular}

Note: Values in a column with different lowercase mean significant difference $(P<0.05)$, same lowercase mean no significant difference $(P>0.05)$.

The effect of distilled leaf litter of E. grandis on growth indexes were also tested as blank control in our trial (Table 2). There was no remarkable difference in all growth indexes among four groups at the day of 30,60 and $90(P>0.05)$. 
Table 2. Effect of distilled leaf litter of E. grandis on growth indexes of E. ophiuroides

\begin{tabular}{cccccc}
\hline $\begin{array}{c}\text { Days after } \\
\text { sowing (d) }\end{array}$ & Groups & $\begin{array}{c}\text { Root length } \\
(\mathrm{cm})\end{array}$ & $\begin{array}{c}\text { Plant height } \\
(\mathrm{cm})\end{array}$ & $\begin{array}{c}\text { Fresh weight } \\
(\mathrm{g} / \mathrm{plant})\end{array}$ & $\begin{array}{c}\text { Dry weight } \\
(\mathrm{g} / \mathrm{plant})\end{array}$ \\
\hline \multirow{6}{*}{30} & CK & $8.02 \pm 0.98^{\mathrm{a}}$ & $10.61 \pm 2.12^{\mathrm{a}}$ & $0.51 \pm 0.12^{\mathrm{a}}$ & $0.15 \pm 0.02^{\mathrm{a}}$ \\
& A1 & $8.31 \pm 1.28^{\mathrm{a}}$ & $10.33 \pm 2.76^{\mathrm{a}}$ & $0.50 \pm 0.13^{\mathrm{a}}$ & $0.15 \pm 0.02^{\mathrm{a}}$ \\
& A2 & $7.91 \pm 1.31^{\mathrm{a}}$ & $10.55 \pm 3.01^{\mathrm{a}}$ & $0.50 \pm 0.14^{\mathrm{a}}$ & $0.15 \pm 0.02^{\mathrm{a}}$ \\
& A3 & $8.21 \pm 1.01^{\mathrm{a}}$ & $10.51 \pm 2.99^{\mathrm{a}}$ & $0.49 \pm 0.09^{\mathrm{a}}$ & $0.15 \pm 0.02^{\mathrm{a}}$ \\
& CK & $12.39 \pm 2.78^{\mathrm{a}}$ & $19.21 \pm 2.41^{\mathrm{a}}$ & $1.13 \pm 0.12^{\mathrm{a}}$ & $0.29 \pm 0.07^{\mathrm{a}}$ \\
60 & A1 & $12.47 \pm 2.12^{\mathrm{a}}$ & $19.02 \pm 3.03^{\mathrm{a}}$ & $1.13 \pm 0.14^{\mathrm{a}}$ & $0.28 \pm 0.07^{\mathrm{a}}$ \\
& A2 & $12.19 \pm 1.98^{\mathrm{a}}$ & $19.18 \pm 2.79^{\mathrm{a}}$ & $1.12 \pm 0.11^{\mathrm{a}}$ & $0.29 \pm 0.10^{\mathrm{a}}$ \\
& A3 & $12.31 \pm 2.65^{\mathrm{a}}$ & $19.22 \pm 2.16^{\mathrm{a}}$ & $1.12 \pm 0.13^{\mathrm{a}}$ & $0.29 \pm 0.11^{\mathrm{a}}$ \\
& CK & $15.21 \pm 3.13^{\mathrm{a}}$ & $28.11 \pm 3.97^{\mathrm{a}}$ & $3.65 \pm 0.56^{\mathrm{a}}$ & $0.65 \pm 0.18^{\mathrm{a}}$ \\
& A1 & $15.65 \pm 3.01^{\mathrm{a}}$ & $27.98 \pm 4.01^{\mathrm{a}}$ & $3.61 \pm 0.49^{\mathrm{a}}$ & $0.64 \pm 0.19^{\mathrm{a}}$ \\
& A2 & $15.09 \pm 2.11^{\mathrm{a}}$ & $28.16 \pm 3.19^{\mathrm{a}}$ & $3.67 \pm 0.51^{\mathrm{a}}$ & $0.62 \pm 0.17^{\mathrm{a}}$ \\
& A3 & $15.22 \pm 2.18^{\mathrm{a}}$ & $28.02 \pm 4.11^{\mathrm{a}}$ & $3.71 \pm 0.67^{\mathrm{a}}$ & $0.65 \pm 0.18^{\mathrm{a}}$
\end{tabular}

Note: Values in a column with different lowercase mean significant difference $(P<0.05)$, same lowercase mean no significant difference $(P>0.05)$.

\subsection{Effect of Decomposing Leaf Litter of E. grandis on MDA Content and Antioxidant Enzyme Activity in E. ophiuroides}

MDA content in A3 was significantly higher than that in CK, A1, and A2 groups at the day of $30(P<0.05)$, and no significant difference was found among A1, A2 and CK. However, the MDA content significantly went up with the increase of amount of leaf litter at the day of 60 , namely $\mathrm{CK}<\mathrm{A} 1<\mathrm{A} 2<\mathrm{A} 3(P<0.05)$. MDA in all treatments were significantly higher than that in CK at day of $90(P<0.05)$ (Figure 1). The SOD activity was significantly affected by leaf litter at day of 30,60 and 90, but displayed different change trends at time points (Figure 2A). At day of 30, the SOD activity in three treatments were same as that in CK, and the one in A1 was significantly higher than those in A2 and A3 $(P<0.05)$. However, significant differences were observed between different treatments and $\mathrm{CK}$ at the day of 60 and $90(P<0.05)$. There were significant differences between treatments and CK found in the POD activity at three time points $(P<0.05)$ (Figure 2B). The activity of POD in $\mathrm{A} 2$ and $\mathrm{A} 3$ group were significantly lower than that in A1 at day of 30 and $90(P<0.05)$, and POD activity in A1 and A2 were significantly higher than that in $\mathrm{A} 3$ at day of $60(P<0.05)$. The CAT activity were similar to those among $\mathrm{CK}, \mathrm{A} 1$ and $\mathrm{A} 2$, but the one in A1 was significantly higher than that in $\mathrm{A} 3$ at day of $30(P<0.05)$. The CAT activity decreased with the rising of leaf litter content at the day of 60 and 90, CK $>A 1>A 2>A 3$ (Figure 2C).

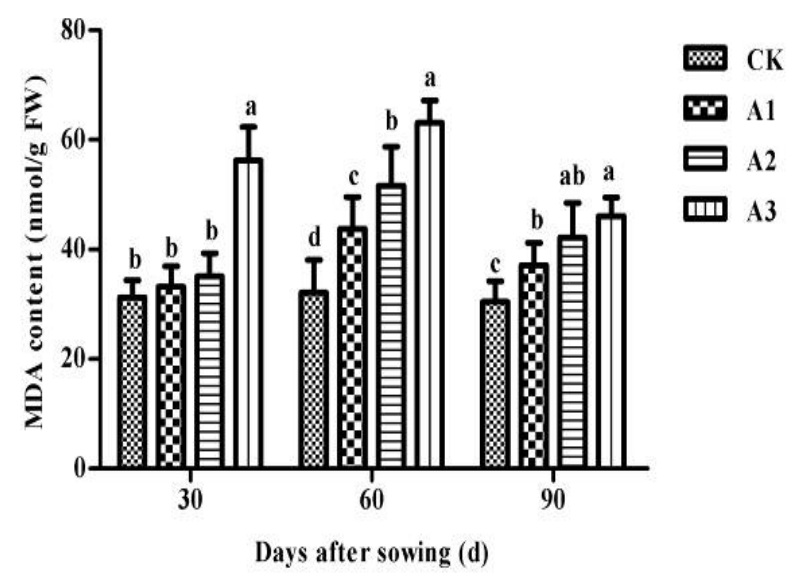

Figure 1. Effects of decomposing leaf litter of E. grandis on the MDA content in E. Ophiuroides 
Different lowercase above the columns indicate significant differences $(P<0.05)$, same lowercase above the columns indicate significant differences $(P>0.05)$.
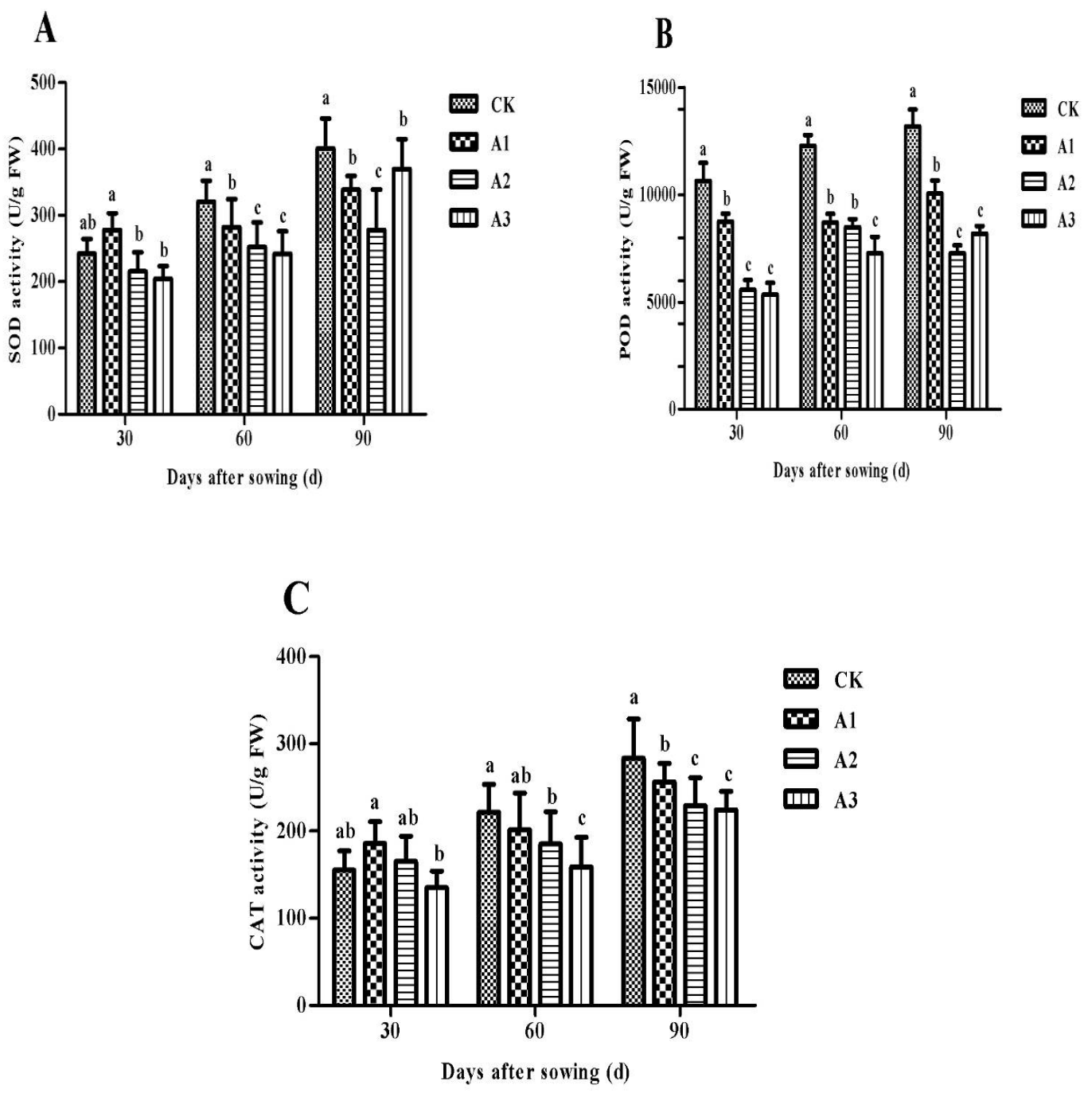

Figure 2. Effects of decomposing leaf litter of E. grandis on the antioxidant enzyme activity in E. ophiuroides Different lowercase above the columns indicate significant differences $(P<0.05)$, same lowercase above the columns indicate significant differences $(P>0.05)$.

\subsection{Effect of Decomposing Leaf Litter of E. grandis on Osmotic Adjustment Materials in E. ophiuroides}

The effect of decomposing leaf litter on osmotic adjustment materials (soluble sugar and soluble protein) were analyzed in our trial (Figure 3). The change trends of soluble protein content at different times were opposite to that of soluble sugar contents. The soluble sugar contents went up with the increase of leaf litter contents at day 30, 60 and 90, whereas, the soluble protein contents dropped with rising of leaf litter contents. The soluble sugar contents in treatments were significantly different with that in $\mathrm{CK}$ at all three tested time-points $(P<0.05)$. For soluble protein content, $\mathrm{CK}$ was similar to A1 and significantly higher than A2 and A3 at day of $30(P<0.05)$. There were significant differences among four groups at day of $60(P<0.05)$. CK group was significantly higher than those in A2 and A3 $(P<0.05)$, but was same as that in A1 group at day 90. 

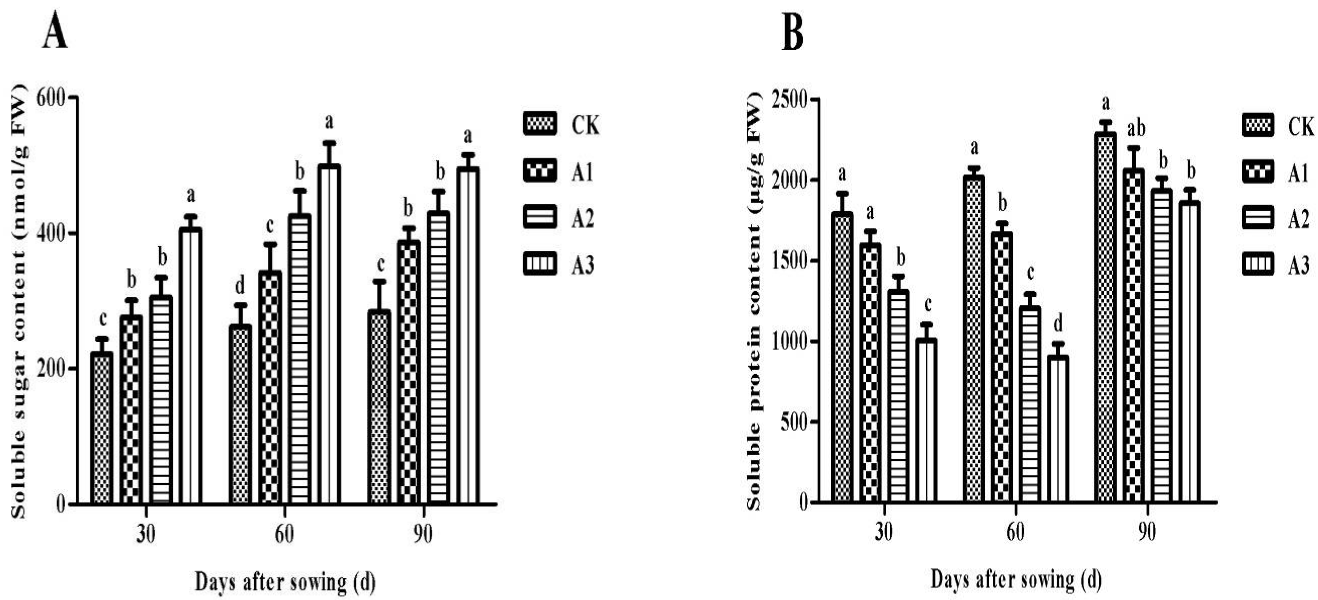

Figure 3. Effects of the leaf litter of E. grandis on the soluble sugar content and soluble protein content in E. ophiuroides

Different lowercase above the columns indicate significant differences $(P<0.05)$, same lowercase above the columns indicate significant differences $(P>0.05)$.

\section{Discussion}

Leaf litter is the main component of forest ecosystem, as well as the primary source of matter and energy for decomposers. Leaf litter is very important for the forest ecosystems to remain its structure and function, and is also significant associated with the reforestation (McClaugherty et al., 1985). However, certain chemicals released from decomposing leaf litter also can influence the germination and growth of plants (Lousier \& Parkinson, 1978). Alkane, alkene, alcohol, phenol, ester and other chemical compounds were identified from $E$. grandis fallen leaves by gas chromatograph-mass spectrometer (GC-MS), and many of them have been proven to have allelopathic effect on other plants, microbes and insects (Gao et al., 2008). Other reports showed that once allelochemicals release into environment by decomposition, some of them directly affect receptors, and others can take functions after transformation and modification by microbes and enzymes in soil (Fujii et al., 2004; Weiner, 2001). The blank experiment of adding E. grandis fallen leaves in which allelochemicals have been removed by distilling showed that there was no significant difference found among groups in all growth indexes of E. ophiuroides. This illustrated that the growth of E. ophiuroides had not been affected after adding the distilled fallen leaves into the soil. Thus, this study argued that the effect on growth and physiological indexes of E. ophiuroides was mainly caused by allelochemicals which was released from decomposing leaf litter of E. Grandis.

Studies of modern plant physiology indicate that the amount of reactive oxygen species (ROS) such as $\mathrm{H}_{2} \mathrm{O}_{2}$ and $\mathrm{O}_{2}^{-}$will increase in the plant under the adversity conditions. Then, the ROS content, as a stress signal, which can stimulate the expression of stress-tolerance genes, and gradually establish the defense system to stress (Bayr, 2005). However, ROS has strong oxidation effect, and the cell membrane will be peroxidized to yield MDA (Apel \& Hirt, 2004). In this case, expressions of a series of antioxidant protective enzymes could be induced to increase in the plant. The $\mathrm{O}_{2}^{-}$can be transformed to $\mathrm{H}_{2} \mathrm{O}_{2}$ by disproportionation of SOD, then, CAT and POD can reduce the $\mathrm{H}_{2} \mathrm{O}_{2}$ to non-poisonous $\mathrm{H}_{2} \mathrm{O}$ and $\mathrm{O}_{2}$, thus preventing the destruction to the cell membrane caused by ROS (Slesak et al., 2007). In our research, the activities of SOD and CAT increased in response to stress stimulation at low content of fallen leaves and less processing time, which probably contributes to clean up the ROS. Because the stress of allelopathy may not strong enough and the amount of ROS was limited in this condition, the scavenging effect of SOD and CAT can play the protection role in cell membrane. Thus, the content of MDA in CK group had no significant difference, compared with $30 \mathrm{~g} / \mathrm{pot}$ and $60 \mathrm{~g} /$ pot treatments in early stage of experiment, but was remarkable different with $90 \mathrm{~g} /$ pot treatment. As the increase of leaf litter content or processing duration, the ROS dramatically rose and passed the threshold of scavenging by protective enzyme, then significant differences in MDA among four groups were observed at day of $60(P<0.05)$. However, the MDA contents decreased in treatments at day of 90 . This indicated that the allelopathy may slow down after decomposition of E. grandis for over three months, and probably the adaptability of E. ophiuroides 
went up to a certain degree with its growth.

The activities of POD were remarkably inhibited at processing time and in different treatment groups, which indicated that the POD was very sensitive to allelochemicals of fallen leaves in E. ophiuroides or POD can be damaged by ROS. What's more, POD can not only clear $\mathrm{H}_{2} \mathrm{O}_{2}$, but also play important roles in respiratory metabolism and promoting the transformation from phenols to lignin (Harvey et al., 1976). Therefore, allelochemicals can disturb the respiration and lignin synthesis by means of affecting the POD activity, and influence the accumulation of biomass in E. ophiuroides finally.

The soluble sugars can keep the intracellular osmosis pressure and play an important roles in maintaining the normal physiological function of cells (Kohyama \& Nishinari, 1991). The soluble proteins with colloidal properties are main components in cell matrix, and they can increase protoplasm hydration (Fisher et al., 1992). In current study, the soluble sugar content increased remarkably under the impact of decomposition of leaf litter in soil $(P<0.05)$. This suggested that allelochemicals can hinder the ability of E. ophiuroides to absorb water and cause a certain degree of water stress, so that the accumulation of soluble sugar was increased in the body of E. ophiuroides. Wang et al. (2005) also thought that allelochemicals can influence the plant roots' absorption of water (Wang et al., 2005). It may also be that allelopathy stress caused degradation of macromolecular sugar and protein, and then transformed into sucrose, glucose and other micromolecular soluble sugars. The changing trend of soluble sugar in our research was consistent with the previous report that the soluble sugar content of main pasture plants in psychro-grassland increased under the allelopathic stress of aqueous extracts from Liqularia viraurea (Zhu et al., 2007).

\section{Conclusion}

In conclusion, the allelopathy caused by allelochemicals released from decomposing E. Grandis leaf litter can significantly influence resistance physiology traits includes MDA content, antioxidant enzyme activity and osmotic adjustment materials, and leading to disturbance in physiology that ultimately inhibit the growth indexes of E. ophiuroides. Thus, the allelopathic effect of leaf litter should be controlled effectively in the compound planting of grass and E. grandis plantation.

\section{Acknowledgements}

This study was financially supported by the National Key Technology R\&D Programs of China during $11^{\text {th }}$ and $12^{\text {th }}$ Five-Year Plan Period (No. 2008BADC2B01 and No. 2011BAC09B05).

\section{References}

Aebi, H. (1984). Assays of catalase in vitro. Catalase in vitro, 105, 122-126.

Apel, K., \& Hirt, H. (2004). Reactive oxygen species: metabolism, oxidative stress, and signal transduction. Annual Review of Plant Biology, 55, 373-399. http://dx.doi.org/10.1146/annurev.arplant.55.031903.141701

Bayr, H. (2005). Reactive oxygen species. Critical care medicine, 33(12), S498-S501. http://dx.doi.org/10.1097/01.CCM.0000186787.64500.12

Christian, J. M., \& Wilson, S. D. (1999). Long-term ecosystem impacts of an introduced grass in the northern Great Plains. Ecology, 80(7), 2397-2407. http://dx.doi.org/10.2307/176919

Curtis, R. O. (1971). Reviews: The Principles of Forest Yield Study. Forest Science, 17(4), 498-498.

Fisher, D. B., Wu, Y., \& Ku, M. S. B. (1992). Turnover of soluble proteins in the wheat sieve tube. Plant Physiology, 100(3), 1433-1441. http://dx.doi.org/10.1104/pp.100.3.1433

Florence, R. G. (1986). Cultural problems of Eucalyptus as exotics. Commonwealth Forestry Review, 65(2), 141-163.

Fujii, Y., Shibuya, T., Nakatani, K., Itani, T., Hiradate, S., \& Parvez, M. M. (2004). Assessment method for allelopathic effect from leaf litter leachates. Weed Biology and Management, 4(1), 19-23. http://dx.doi.org/10.1111/j.1445-6664.2003.00113.x

Gao, D., Hu, T. X., Wan, X., T.Y., T., \& Chen, L. H. (2008). Allelopathic constituents from litter fall of Eucalyptus grandis. Journal of Zhejiang Forestry College, 25(2), 191-194 (In Chinese).

Giannopolitis, C. N., \& Ries, S. K. (1977). Superoxide dismutases I. Occurrence in higher plants. Plant Physiology, 59(2), 309-314. http://dx.doi.org/10.1104/pp.59.2.309

Guo, Q. (2007). Ecological problem and development countermeasure of Eucalyptus. Hunan Forestry Science \& Technology, 2, 27-31 (In Chinese). 
Harvey, D. M., Hedley, C. L., \& Keely, R. (1976). Photosynthetic and respiratory studies during pod and seed development in Pisum sativum L. Annals of Botany, 40(5), 993-1001.

Heath, R. L., \& Packer, L. (1968). Photoperoxidation in isolated chloroplasts: I. Kinetics and stoichiometry of fatty acid peroxidation. Archives of Biochemistry and Biophysics, 125(1), 189-198. http://dx.doi.org/10.1016/0003-9861(68)90654-1

Islam, M. A., \& Hirata, M. (2005). Centipedegrass (Eremochloa ophiuroides (Munro) Hack.): Growth behavior $\begin{array}{llll}\text { and multipurpose } \quad \text { usages. } & \text { Grassland }\end{array}$ http://dx.doi.org/10.1111/j.1744-697X.2005.00014.x

Kohyama, K., \& Nishinari, K. (1991). Effect of soluble sugars on gelatinization and retrogradation of sweet potato starch. Journal of Agricultural and Food Chemistry, 39(8), 1406-1410. http://dx.doi.org/10.1021/jf00008a010

Li, H. S. (2000). The Experiment Principle and Technology of Plant Physiology. Beijing: Higher Education Press (In Chinese). http://dx.doi.org/10.1104/pp.124.3.1315

Liu, H., \& Li, J. (2010). The study of the ecological problems of eucalyptus plantation and sustainable development in Maoming Xiaoliang. Journal of Sustainable development, 3(1), 197-199 (In Chinese).

Lousier, J. D., \& Parkinson, D. (1978). Chemical element dynamics in decomposing leaf litter. Canadian Journal of Botany, 56(21), 2795-2812. http://dx.doi.org/10.1139/b78-335

McClaugherty, C. A., Pastor, J., Aber, J. D., \& Melillo, J. M. (1985). Forest litter decomposition in relation to soil nitrogen dynamics and litter quality. Ecology, 266-275. http://dx.doi.org/10.2307/1941327

Niakan, M., \& Saberi, K. (2009). Effects of Eucalyptus allelopathy on growth characters and antioxidant enzymes activity in phalaris weed. Asian Journal of Plant Sciences, 8(6), 440-446. http://dx.doi.org/10.3923/ajps.2009.440.446

Slesak, I., Libik, M., Karpinska, B., Karpinski, S., \& Miszalski, Z. (2007). The role of hydrogen peroxide in regulation of plant metabolism and cellular signalling in response to environmental stresses. Acta Biochimica Polonica, 54(1), 39.

Wang, C. X., Zhu, M. X., Chen, X. H., \& Qu, B. (2011). Review on Allelopathy of Exotic Invasive Plants. Procedia Engineering, 18, 240-246. http://dx.doi.org/10.1016/j.proeng.2011.11.038

Wang, H., Li, X., \& Li, S. (2003). Study of forest-grass compound management mode. Sichuan Forestry Exploration and Design, 1-5 (In Chinese).

Wang, Q., Sun, H. J., \& Sun, N. Q. (2005). Allelochmical and action mechanism. China Vegetable, 70-74 (In Chinese).

Weiner, J. (2001). Plant allelochemical interference or soil chemical ecology? Perspectives in Plant Ecology, Evolution and Systematics, 4(1), 3-12. http://dx.doi.org/10.1078/1433-8319-00011

Yang, J. C. (1997). Compound planting model and agricultural sustainable development. Ecological Economy, 4, 8-11 (In Chinese).

Zhang, C., \& Fu, S. (2009). Allelopathic effects of eucalyptus and the establishment of mixed stands of eucalyptus and native species. Forest Ecology and Management, 258(7), 1391-1396. http://dx.doi.org/10.1016/j.foreco.2009.06.045

Zhang, J. E. 2006. The Methods and Technologies of Common Experiment in Ecology. Beijing: Chemical Industry Press (In Chinese).

Zhu, H., Ma, R. J., Chen, S. S., \& Wang, M. L. (2007). Physiological response of main pasture plants in psychro-grassland to allelopathic stress of aqueous extracts from Ligularia Virgaurea. Acta Prataculturae Sinica, 16(5), 102-106 (In Chinese). 